\title{
PENDAMPINGAN BADAN USAHA MILIK DESA (BUMDES) DALAM OPTIMALISASI POTENSI DESA DI DESA CEPAKA TABANAN-BALI
}

\author{
I Nengah Aristana ${ }^{1, *)}$, I Made Yudi Darmita ${ }^{2}$, I Putu Bagus Suthanaya ${ }^{3}$, Putu \\ Agus Prayogi ${ }^{4}$ \\ (Fakultas Bisnis dan Sosial Humaniora, Universitas Triatma Mulya ${ }^{1,2,3}$ ) \\ (Fakultas Pariwisata, Universitas Triatma Mulya ${ }^{4}$ ) \\ nengah.aristana@triatmamulya.ac.id ${ }^{*}$
}

\begin{abstract}
Community service that is carried out has a purpose, namely it is expected to be able to provide benefits in the form of increasing entrepreneurial practices, related; maximizing potential, management capabilities, understanding business plans and their implementation, as well as increasing the ability to collaborate with external parties. In addition, it can improve business management that has been running and improve the quality of records owned. The methods used are 1) the presentation method is used to deliver detailed material and examples related to entrepreneurship, 2) the discussion method, 3) the simulation method and operational assistance. The activity was attended by the Cepaka Village BUMDes management/manager. Based on the assistance provided and observations, it can be seen that the participants followed and responded positively to each given program. Furthermore, they feel this assistance is very useful to assist them in carrying out their business operations.
\end{abstract}

Keywords: a maximum of five keywords that are sufficient to describe a large subject written in the article, in English and arranged in alphabetical order (Times New Roman, 12 pt, italics).

\section{PENDAHULUAN}

Desa saat ini menjadi salah satu ujung tombak pembangunan negara khususnya Indonesia. Berbagai upaya dilakukan pemerintah untuk mendorong peningkatan ekonomi desa dengan memberikan stimulus berupa Dana Desa dan Program pengembangan Badan Usaha Milik Desa (BUMDes) (Hidayah et al., 2018; Risal et al., 2020). BUMDes merupakan badan usaha yang sebagian atau seluruh modal usahanya dimiliki desa yang berasal dari kekayaan desa yang dipisahkan untuk mengelola aset, jasa pelayanan, dan usaha yang digunakan

mensejahterakan masyarakat desa (Anggraeni, 2016). Berdasarkan Undang-undang Nomer 4 Tahun 2015 pendirian BUMDes memiliki tujuan untuk meningkatkan perekonomian desa, mengoptimalkan aset desa, pengelolaan potensi desa, menciptakan peluang, membuka lapangan pekerjaan, meningkatkan kesejahteraan masyarakat desa, dan meningkatkan pendapatan masyarakat desa (Agunggunanto et al., 2016; Hidayat et al., 2018; Ainiyah, Diah and Aprilia, 2020; Risal et al., 2020)

Dari 455 BUMDes yang ada di Bali, 334 unit usaha bergerak pada unit simpan pinjam. Pada dasarnya 
BUMDes memiliki potensi besar untuk mengangkat perekonomian desa. Seperti halnya BUMDes yang ada di Bali yang kental dengan adat istiadatnya. BUMDes di Bali memiliki potensi luar biasa seperti; perkebunan, pertanian dan pariwisata. Seperti halnya desa-desa yang ada di Bali, Desa Cepaka merupakan salah satu desa yang memiliki potensi yang begitu banyak. Selain sebagai desa dengan potensi pertanian dan perkebunan, desa ini merupakan salah satu desa wisata yang ada di Bali. Sehingga dari berbagai potensi yang dimiliki, BUMDes di desa ini harusnya mampu menguatkan mengembangkan unit usahanya. Namun sayangnya BUMDes yang ada di desa Cempaka saat ini juga bergerak di unit simpan pinjam sebagai core utama, selain usaha pelayanan masyarakat seperti pembayaran listrik, samsat dan pajak.

Sebagai desa wisata pastinya ada banyak akomodasi perhotelan yang dibangun di desa ini, seperti; villa dan home stay, atraksi (jogging track), pusat kuliner dan kolam pemancingan. Serta saat ini sedang dikembangkan spot wisata arung jeram. Banyaknya potensi ini harusnya dapat dimanfaatkan oleh BUMDes untuk mengembangkan usahanya. Melihat potensi yang dimiliki harus BUMDes Desa Cepaka tidak hanya terbatas pada unit simpan pinjam serta pelayanan yang bersifat periodik. Berdasarkan analisis situasi yang dilakukan oleh tim, maka dapat diketahui beberapa permasalahan yang dihadapi BUMDes Desa Cempaka sebagai Mitra.

Adapun permasalahan dari BUMDes Desa Cepaka antara lain: masih kurangnya wawasan kewirausahaan untuk memanfaatkan pontensi yang ada, serta pengelolaan usaha yang masih belum terorganisir dengan baik. Melihat permasalahan yang dipaparkan diatas, maka dipandang penting untuk melakukan pelatihan kewirausahaan bagi pengelola BUMDes dan melakukan pendampingan pengelolaan usaha. Tujuan dari program ini diharapkan mampu memberikan manfaat berupa peningkatan praktek kewirausahaan, terkait; memaksimalan potensi, kemampuan manajemen, pemahaman rencana bisnis dan penerapannya, serta meningkatkan kemampuan dalam menjalin kerjasama dengan pihak eksternal. Selain itu dapat meningkatkan pengelolaan usaha yang selama ini sudah berjalan dan peningkatan kualitas pencatatan yang dimiliki.

\section{METODE PELAKSANAAN}

Pelaksanaan

program

pengabdian kepada masyarakat ini, diawali dengan menyusun materi pelatihan yang disesuaikan dengan kebutuhan pihak BUMDes di Desa Cepaka. Materi disajikan pada pelatihan membantu pengembangan wawasan entrepreneurial di Desa Cepaka Badung terkait dengan analisa peluang, manajemen, dan membangun jaringan mengingat poin penting pelatihan ini adalah memberikan sebuah wawasan entrepreneurial untuk pengelola BUMDes sehingga dapat membantu dan memudahkan para karyawan dalam mengembangkan BUMDes. Wawasan kewirausahaan menjadi sangat penting untuk para karyawan karena sudah seharusnya BUMDes lebih produktif dalam usahanya. Dengan wawasan kewirausahaan menjadikan karyawan untuk lebih giat mengembangkan BUMDes. Adapun metode yang digunakan dalam kegiatan pelatihan 
SAVE: Synergy and Society Service

Vol 1, No 2, Desember 2021 hal. 48 - 55

(I Nengah Aristana ${ }^{1}$, I Made Yudi Darmita ${ }^{2}$ I Putu Bagus Suthanaya ${ }^{3}$, Putu Agus Prayogi ${ }^{4}$ )

adalah presentasi, diskusi dan simulasi dilakukan dengan simulasi. 1) metode presentasi menganalisa usaha-usaha yang sukses digunakan untuk menyampaikan dan gagal sebagai bahan pembelajaran materi dan contoh secara rinci terkait dengan kewirausahaan, 2) metode diskusi digunakan untuk mengakomodir pertanyaan yang dimiliki peserta terkait dengan materi yang telah disampaikan, 3) metode dan 4) pendampingan operasional. Pelaksanaan pengabdian kepada masyarakat ini, dimulai dengan penyusunan program kegiatan dan pembagian tugas dari masing-masing tim (Gambar 1).

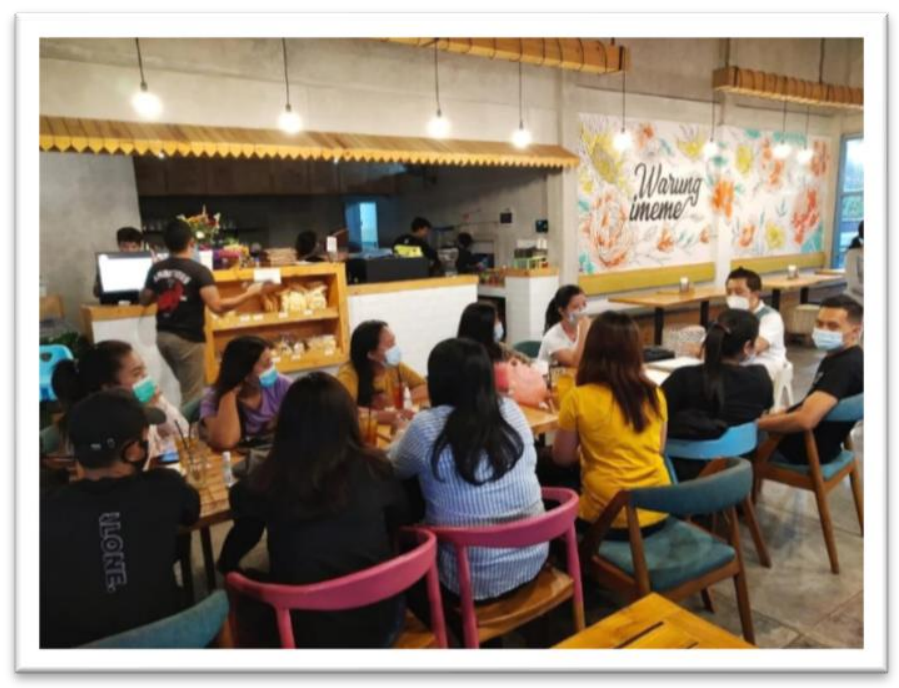

\section{Gambar 1. Perancangan Program Dengan Tim Pelaksana}

Tahap kedua mengenalkan tim pengelola BUMDes di Desa Cepaka yang terlibat dengan pendampingan (Gambar 2).

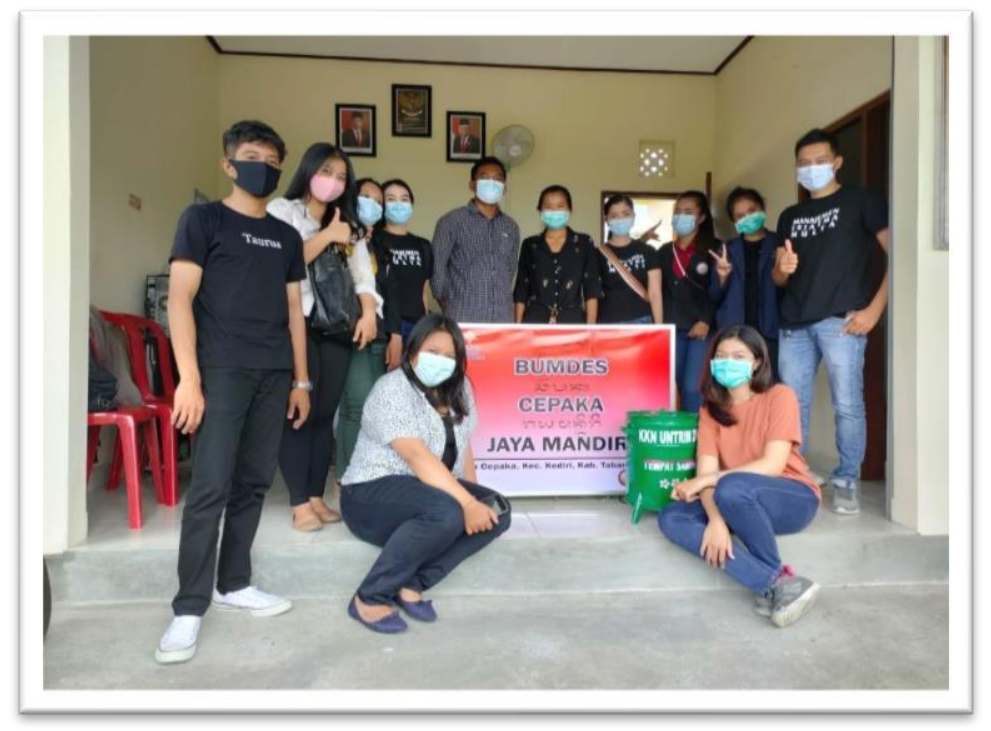

Gambar 2. Pengenalan Tim Pengabdian Masyarakat 
Kegiatan ini dilaksanakan dari bulan Nopember s/d Desember 2020, dengan melibatkan 10 orang mahasiswa Program Studi S1 Manajemen dan Program Studi S1
Akuntansi, Fakultas Bisnis dan Sosial Humaniora Universitas Triatma Mulya, dengan jadwal kegiatan sebagai berikut;

Tabel 1

Jadwal Kegiatan

\begin{tabular}{|c|c|c|c|}
\hline \multirow[t]{2}{*}{ No } & \multirow[t]{2}{*}{ Kegiatan } & \multicolumn{2}{|c|}{ Bulan } \\
\hline & & Nopember & Desember \\
\hline 1 & $\begin{array}{l}\text { Lokakarya "topik kewirausahaan" } \\
\text { Materi: } \\
\text { 1. Analisa situasi lingkungan internal } \\
\text { dan eksternal BUMDes } \\
\text { 2. Analisa peluang dan bagaimana } \\
\text { mengisi peluang yang ada. } \\
\text { 3. Membangun jaringan usaha }\end{array}$ & & \\
\hline 2. & Pemdampingan Pengelolaan & & \\
\hline & $\begin{array}{l}\text { Kegiatan: } \\
\text { 1. Mengarahkan dan membina dalam } \\
\text { pembuatan laporan harian (intern } \\
\text { control) } \\
\text { 2. Membantu membuatkan pola } \\
\text { transaksi yang transparan } \\
\text { 3. Membuatkan standar operasional } \\
\text { prosedur (SOP) untuk unit usaha } \\
\text { simpan pinjam }\end{array}$ & & \\
\hline
\end{tabular}

\section{HASIL DAN PEMBAHASAN}

Program lokakarya dan pendampingan ini sebagai bentuk dari pengabdian kepada masyarakat memperoleh sambutan yang positif dari pihak mitra yakni Desa Cepaka. Penerimaan ini disebabkan karena program pendampingan ini sesuai dengan kebutuhan desa untuk memajukan BUMDes melalui pengelolaan berkesinambungan.

\section{a. Program Lokakarya}

Lokarya ini diikuti oleh para pengurus BUMDes dengan secara aktif dalam semua proses kegiatan, meskipun acara yang dilakukan tidak dalam situasi formal disesuaikan dengan permintaan seperti dilihat pada gambar 3. 


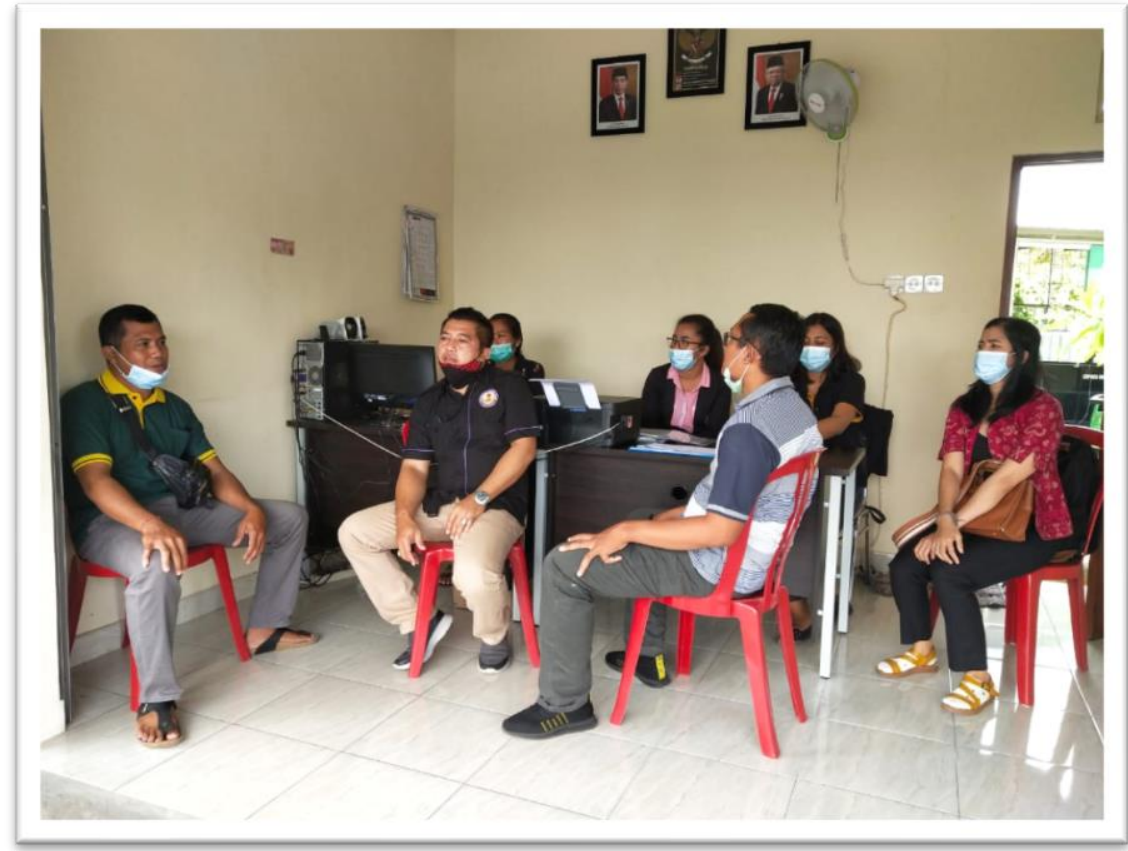

Gambar 3

Pemaparan Materi Lokakarya

Penyampaian materi kepada peserta dilakukan dalam tiga sub bahasan, selanjutnya dilakukan diskusi tekait sub materi dan kondisi yang terjadi, diakhiri dengan review singkat terhadap materi yang telah disampaikan. Berdasarkan lokakarya ini perserta merasa memiliki pengetahuan baru terkait dengan materi yang diberikan:

1. Analisa situasi lingkungan internal dan eksternal BUMDes

Materi ini dapat tersampaikan serta diterima dengan baik, dengan akumulasi serapan mencapai $75 \%$. Ini terlihat dari bagaimana perserta memberikan respon terhadap materi ini, serta mereka mampu melakukan pemetaan terhadap situasi yang ada di dalam BUMDes. Selain itu, mereka mampu memberikan asumsi-asumsi terkait dengan keberadaan BUMDes dilingkungan eksternal, serta mampu memposisikan BUMDes diantara usaha lainnya. Pada program selanjutnya akan dilakukan analisis SWOT untuk menentukan strategi pengembangan BUMDes dimasa depan.

2. Analisa peluang dan bagaimana mengisi peluang yang ada.

Materi ini dapat terdistribusi dengan baik, dengan akumulasi serapan mencapai $80 \%$. Hal ini ditunjukkan dengan respon yang diberikan dan peserta mampu membuat list peluang-peluang yang mungkin diisi dan rencana usaha yang mungkin dikembangkan dimasa yang akan datang. Namun demikian 
mereka masih harus bersabar karena situasi pandemic covid 19 belum berakhir, membuat mereka masih belum mampu secara maksimalkan pontensi yang ada.

3. Membangun jaringan usaha Materi membangun jaringan usaha dapat diterima dengan sangat baik, dengan perkiraan akumulasi serapan mencapai $85 \%$. Hal ini ditunjukkan dengan antusiasme yang tinggi serta respon yang sangat baik. Selain itu, mereka telah merangcang kerjasama dan akan melakukan penjajakan dengan usaha yang ada dilingkungan BUMDes.

\section{b. Pemdampingan Pengelolaan}

Pendampingan pengelolaan dalam program pengabdian kepada masyarakat dilakukan oleh mahasiswa yang dilibatkan yaitu Mahasiswa Program Studi S1 Manajemen dan S1 Akuntansi, Fakultas Bisnis dan Sosial Humaniora Universitas Triatma Mulya. Mahasiswa dibagi ke dalam tiga kelompok, yang selanjutnya disebut tim satu (3 orang), tim dua (4 orang) dan tim tiga (3 orang). Untuk pelaksanaan pendampingan dilakukan sebanyak tiga kali seminggu yang dijadwalkan setiap hari sening, rabu dan jumat.

1. Mengarahkan dan membina dalam pembuatan laporan harian.

Pendampingan dilakukan tim pertama dengan memberikan masukan serta diskusi terkait dengan pembuatan laporan harian. Selama ini BUMDes jarang membuat laporan terkait dengan kegiatan operasional harian, pembuatan laporan hanya dilakukan secara bulanan. Meskipun ini tidak salah namun dipandang penting untuk membuat laporan harian untuk mencegah ada kegiatan yang tidak terlaporkan. Setelah dilakukan pendampingan laporan harian mulai dibuat dan dinyatakan membantu serta meringankan dalam membuat laporan bulanan. Sehingga pendampingan ini dinyatakan efektif.

2. Membantu membuatkan pola transaksi yang transparan

Pendampingan ini dilakukan oleh tim kedua, seperti program sebelumnya pendampingan dilakukan dengan memberikan masukan dan diskusi mengenai prosedur operasional teller/kasir, meliputi pembuatan laporan penyerahan kas awal teller, validasi transaksi, transaksi harian teller, laporan pengembalian kas akhir teller, berita acara uang kas dan pengarsipan seluruh berkas transaksi. Memberikan saran pembuatan SOP pemeliharaan kas agar kas tunai setiap harinya tidak dalam jumlah besar. Membantu dan mengajarkan penyusunan laporan keuangan dan pembuatan laporan berita acara uang kas. Sehingga pendampingan ini dinyatakan dapat membantu mereka untuk menjaga pola transaksi dan menjaga transparansi.

3. Membuatkan standar operasional prosedur (SOP) 
untuk unit usaha simpan pinjam

Pendampingan ini dilakukan oleh tim ketiga, pendampingan dilakukan dengan memberikan penjelasan mengenai adanya pasal-pasal dalam perjanjian kredit yang berlaku, serta tata cara pengembalian kredit. Sehingga perlu dilakukan pembuatan standar operasional prosedur (SOP) simpan pinjam. Dengan adanya SOP dapat mencegah dan mengurangi penyaluran kredit yang tidak sesuai di BUMDes. Sehingga pendampingan yang dilakukan diasumsikan dapat membantu BUMDes untuk penyaluran simpan pinjam.

\section{KESIMPULAN}

Peningkatan pemahaman yang memberikan dampak pada pengetahuan, keterampilan dan sikap (kompetensi) para pengurus atau pengelola, menjadikan BUMDes lebih produktif dalam menjalankan usaha. Pemahaman terkait dengan kewirausahaan membuat para pengurus mampu untuk menggali, menemukan, meciptakan dan mengisi peluang menjadikan BUMDes lebih kompetitif dalam persaingan. Peningatan jaringan usaha membantu BUMDes untuk mengembangkan usaha, karena pada dasarnya kesempatan akan datang dari lingkungan terdekat. Melalui pendampingan yang dilakukan menjadikan BUMDes lebih baik dalam melakukan setiap proses usaha mulai dari pembuatan laporan, transparansi dan mengetahui aturanaturan yang berlaku. Semuanya akan memberikan dampak positif untuk keberlanjutan BUMDes dimasa yang akan datang. Meskipun program ini masih memiliki banyak keterbatasan, namun diharapkan untuk programprogram selanjutnya untuk lebih mengarah pada pengembangan BUMDes.

Untuk tim pelaksana dari program pendampingan ini dapat menjadi pengalaman berharga dan juga menjadi bentuk pelaksanaan tri dharma dimana salah satunya adalah pengabdian kepada masyarakat ini.

\section{UCAPAN TERIMA KASIH}

Pelaksanaan pengabdian kepada masyarakat ini tidak dapat terlaksana sesuai dengan jadwal yang telah disusun tanpa bantuan dan dukungan dari berbagai pihak. Secara khusus penulis mengucapkan terima kasih kepada semua pihak-pihak yang telah memberikan bantuan dan dukungan baik berupa materiil dan moril sehingga program pendampingan sebagai bentuk pengabdian kepada masyarakat dapat terlaksana dengan sangat baik. Adapun ucapan terima kasih disampaikan kepada:

1. Rektor Universitas Triatma Mulya

2. Wakil Rektor dilingkungan Universitas Triatma Mulya

3. Dekan Fakultas Bisnis dan Sosial Humaniora Universitas Triatma Mulya

4. Ketua Program Studi S1 Manajemen dan Akuntansi Fakultas Bisnis dan Sosial Humaniora Universitas Triatma Mulya.

5. Kepala Desa Cepaka beserta jajarannya

6. Ketua BUMDes Desa Cepaka beserta jajarannya

7. Mahasiswa Program Studi S1 Manajemen dan S1 Akuntansi Fakultas Bisnis dan Sosial 
Humaniora Universitas Triatma Mulya yang terlibat dalam program ini

\section{DAFTAR PUSTAKA}

Agunggunanto, E. Y. Arianti, F., Kushartono, E. W., Darwanto. (2016) 'Pengembangan Desa Mandiri Melalui Pengelolaan Badan Usaha Milik Desa (BUMDes)', Dinamika Ekonomi \& Bisnis, 13(1), pp. 67-81.

Ainiyah, N., Diah, R. and Aprilia, R. (2020) 'Pelatihan dan Pendampingan Pengelola Bumdes Dalam Rangka Optimalisasi Potensi Desa Di Desa Pungging Mojokerto', ABDIMAS NUSANTARA: Jurnal Pengabdian Kepada Masyarakat, 2 (1), pp. 251-259.

Amertadewi, T. I. M. and Dwirandra, A. A. N. B. (2013) 'Pengaruh Partisipasi Anggaran Terhadap Kinerja Manajerial Dengan Gaya Kepemimpinan Dan Locus of Control Sebagai Variabel Moderasi', E-Jurnal Akuntansi, 4(3), pp. 550-566.

Hidayah, Z., Mulyana, A., Susanti, E., Lestari, S., Pujiastuti, P. (2018) Pendampingan pengelolaan badan usaha milik desa (bumdes ) dalam kaitannya sebagai infant organisasi', Seminar Nasional Pengabdian Kepada Masyarakat Universitas Terbuka, 1(1), pp. 474-485. Available at: http://prosidingpkmcsr.org/index.php/pkmcsr/a rticle/view/46.

Hidayat, A. T., Pujiati, L., Hidyati, N., Hendrawan, S. A., Suprapto, S.,
Ali, N. (2018) 'Pendampingan Penyusunan Laporan Keuangan Pada Badan Usaha Milik Desa (Bumdes) Lestari Desa Bandung Kecamatan Diwek Jombang', Comvice: Journal of community service, 2(1), pp. 15-20. doi: 10.26533/comvice.v2i1.123

Risal, R., Wulandari, R. and Jaurino, J. (2020) 'Pendampingan Akuntansi Dan Keuangan BUMDes Sedahan Jaya Kecamatan Sukadana Kabupaten Kayong Utara', Cendekia: Jurnal Pengabdian Masyarakat, 2(1), p. 49. doi: 10.32503/cendekia.v2i1.949.

Undang-undang Nomer 4 Tahun 2015 